\title{
“M@dNotes Project”. Giving colour to Grey Literature
}

\section{"Projeto NotasL@cas". Dando cor à Literatura Gris \\ “Proyecto NotasL@cas”. Dando color a la Literatura Gris}

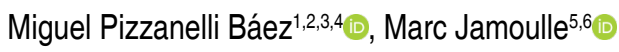 \\ ${ }^{1}$ Departamento de Medicina Familiar y Comunitaria, Facultad de Medicina, UDELAR. Uruguay. \\ ${ }^{2}$ Grupo de trabajo en Prevención Cuaternaria de Uruguay. Uruguay. \\ ${ }^{3}$ Grupo de Prevención Cuaternaria y Sobremedicalizacion de WONCA. \\ ${ }^{4}$ Proyecto NotasL@ cas. Uruguay. \\ ${ }^{5}$ Chercheur associé D2IM, Université de Rouen. France. \\ ${ }^{6}$ Cabinet de Médecine Générale Jamoulle et Associés. Belgium.
}

\begin{abstract}
Sharing the results of research and scientific production is crucial for the survival and development of all disciplines. Health information is becoming uncertain and powerful economic interests disrupting medical information has triggered a loss of credibility. M@dNotes project (in Spanish NotasL@cas), is the by-product of nonprofit collaborative international knowledge network with participation of students, general practitioners, family physicians, and healthcare workers. One of the aims of this network is to discuss the validity of the information available on sensitive subjects and build a knowledge exchange network inside a community of practice. It has been created to share different materials excluded from traditional academic publishing and commercial distribution channels: monographic reports, commented articles, files with references searches. These materials product of learning process are qualified with an appropriate level because there were submitted to a peer review or judged by a scientific committee to get an approval. Includes an indexing method (Q Codes and ICPC) to manage and retrieve the materials received. The project provides a particular folder to upload and share the documents. A web blog is the dissemination friendly tool or interface to share and retrieve the documents available in the network. Through a facility in the cloud, it is possible to access an excel file with all the materials shared, codes assigned and the hyperlink to get a pdf file of each material.
\end{abstract}

Keywords: Family Practice; Scholarly Communication; Publishing; Peer Review

Cite as: Pizzanelli M, Jamoulle M. "M@dNotes Project". Giving colour to Grey Literature. Rev Bras Med Fam Comunidade. 2019;14(41):1759. https://doi.org/10.5712/rbmfc14(41)1759
Corresponding author: Miguel Pizzanelli Báez.

E-mail: miguelpizzanelli@gmail.com Funding: none declared.

Ethical approval: not necessary.

Provenance and peer review: peer reviewed. Received: 05/26/2018. Accepted: 02/03/2019. 


\section{Resumo}

Compartilhar os resultados da pesquisa e da produção científica é crucial para a sobrevivência e o desenvolvimento de todas as disciplinas. A informação de saúde está se tornando incerta e poderosos interesses econômicos que alteram informações médicas causaram uma perda de credibilidade. O projeto M@dNotes (em espanhol NotasL@cas) é o resultado de uma rede de conhecimento internacional colaborativa sem fins lucrativos de estudantes, médicos de família e comunidade e trabalhadores de saúde. Um dos objetivos dessa rede é discutir a validade das informações disponíveis sobre questões sensíveis e construir uma rede de troca de conhecimento dentro de uma comunidade de prática. O objetivo do projeto é compartilhar diferentes materiais excluídos da publicação acadêmica tradicional e dos canais de distribuição comercial: artigos monográficos, comentários sobre artigos, pesquisas de referências. Muitos desses materiais resultantes do processo de aprendizagem atingem um nível adequado de qualidade, porque foram submetidos à revisão por pares ou foram julgados por um comitê científico para obter aprovação. A plataforma inclui um método de indexação (Q-Codes e CIAP-2) para gerenciar e permitir a recuperação de materiais recebidos. O projeto fornece uma ferramenta específica para carregar e compartilhar os documentos. Um web blog é a interfase de difusão amigável e para compartilhar e recuperar os documentos disponíveis nesta rede. Através de uma instalação na nuvem, é possível acessar um arquivo Excel com todos os materiais compartilhados, os códigos atribuídos e o hiperlink para obter o arquivo pdf correspondente para cada material.

Palavras-chave: Medicina de Família e Comunidade; Comunicação Acadêmica; Editoração; Revisão por Pares

\section{Resumen}

Compartir los resultados de investigación y producción científica es crucial para la supervivencia y el desarrollo de todas las disciplinas. La información sanitaria se está volviendo incierta y poderosos intereses económicos que alteran la información médica han provocado una pérdida de credibilidad en ella. El proyecto M@dNotes (en español NotasL@cas) es el resultado de una red de conocimiento internacional colaborativa sin fines de lucro de estudiantes, médicos generales y familiares y trabajadores de la salud. Uno de los objetivos de esta red es discutir la validez de la información disponible sobre temas delicados y construir una red de intercambio de conocimiento dentro de una comunidad de práctica. El propósito del proyecto es compartir diferentes materiales excluidos de la publicación académica tradicional y de los canales de distribución comercial: artículos monográficos, comentarios sobre artículos, archivos con búsquedas de referencias. Muchos de estos materiales producto del proceso de aprendizaje alcanzan un nivel adecuado de calidad, porque fueron sometidos a revisión de pares o han sido juzgados por un comité científico para obtener una aprobación. La plataforma incluye un método de indexación (Códigos-Q e CIAP-2) para administrar y permitir la recuperación de los materiales recibidos. El proyecto proporciona una carpeta particular para cargar y compartir los documentos. Un web blog es la herramienta o interfaz de difusión amigable para compartir y recuperar los documentos disponibles en esta red. A través de una instalación en la nube, es posible acceder a un archivo Excel con todos los materiales compartidos, los códigos asignados y el hipervínculo para obtener el archivo pdf correspondiente a cada material.

Palabras clave: Medicina Familiar y Comunitaria; Comunicación Académica; Edición; Revisión por Expertos

\section{Background}

Unpublished data in General Practice/Family and Community Medicine (GP/FCM) are numerous. Yet, GP/FMC organizations are heavy producers of continuous medical education, training sessions, multiple congresses at local regional and national level in every country. Each year, research meetings, virtual conferences, websites, blogs produce an amount of communicable data usually with restricted circulation in local networks or small groups. They are also active on social networking. For local and national events, the use of local language is the rule. As stated by Eisenbach" "Social networking approaches revolutionize the way people collaborate, identify potential collaborators or friends, communicate with each other, and identify information that is relevant for them". Family physicians are heavy consumer of social media and could appraise internet information and "act as decentralised "label services" to rate the value and trustworthiness of information by putting electronic evaluative and descriptive "tags" on it".

\section{Grey Literature and its relevance in General practice/Family and Community medicine}

Most of these unpublished communications are research production focused on persons, communities and developed at the point of care configured an enormous amount of grey literature. ${ }^{3}$ According to many authors, the term "grey literature" remains not clearly defined, imprecise, confuse and linked to an economic 
point of view. ${ }^{4}$ The Pisa Declaration on Policy Development for Grey Literature Resources includes this definition: Grey literature document types in print or electronic formats include among others: research and technical reports, briefings and reviews, evaluations, working papers, conference papers, theses, and multimedia content, representing an important and valuable part of research and information". ${ }^{5}$

Sharing the results of research and scientific production is crucial for the survival of all disciplines. Therefore, General Practice/Family and Community Medicine (GP/FCM) considered as a discipline with a baggage of knowledge and practices should provide relevance to grey literature and open access to it, through academic and political strategies.

The idea and purpose of working with grey literature produced from GP/FCM is to provide it visibility, utility and contribute to building a network of researchers to share useful knowledge. Systematization for the storage and retrieval of information for research purposes in this field it is necessary. ${ }^{6}$ Actually, the access to scientific literature it is really changing since we have global democratization of knowledge. For example, the explosion of the use of Sci-Hub facilities (http://sci-hub.tw) it is an interesting phenomenon and perhaps it could be the beginning of the end of the scholarly publishing in the way we traditionally understand it. ${ }^{7}$

Recently, a movement of awareness of the uncertainty associated with medical information has arisen in a large number of practitioners. It became apparent that powerful economic interests disrupted medical information and that it was losing credibility. ${ }^{8,9}$ Linked by social media, these family physicians are no longer dependent on their local organization but build trusting relationships around the world. Many of them have become aware of the fragility of their knowledge and have sought to validate their sources of information independently. The movement around the quaternary prevention concept ${ }^{10}$ aims to help disseminate information that protects patients against biased and invasive medical information. This movement, supported by the World Organization of Family Physicians (WONCA) ${ }^{11}$ is putting in place a different means of disseminating quality information. The M@dnotes experience is one of the expressions of this movement.

\section{What is the purpose? Origin of the idea}

The idea of the project arose when verifying that more than $95 \%$ of the postgraduate and pregraduate research/reports/scholar works (monographic works) to accomplish or finished one part of the training were finally lost and unpublished. Most of them come from creative and fresh "minds" and are interesting topics to improve the applying of evidence in medical healthcare. From this perspective, M@dNotes is a unique local platform to rescue knowledge and support exchange and collaboration. Perhaps one limitation is the circumstance of being restricted to few countries or a small group of practice. Nevertheless, the Project is trying to improve its qualifications in order to link $\mathrm{M@dNotes} \mathrm{to} \mathrm{an} \mathrm{open} \mathrm{access} \mathrm{network.} \mathrm{It} \mathrm{has} \mathrm{been} \mathrm{created}$ to share different materials excluded from traditional academic publishing and commercial distribution channels: monographic reports, commented articles, files with references searches.

Many of them qualified with an appropriate level of quality because there were submitted to a peer review or judged by a scientific committee to get an approval. The project includes an indexing method $(Q$ Codes and ICPC) to manage and retrieve the materials received. Q-Codes are intended for indexing Family

medicine related documentation jointly with the International Classification of Primary Care (ICPC) mainly focused on clinical topics. The project provides a particular folder to upload and share the documents. 
A web blog is the dissemination tool or friendly interface to share and retrieve the documents available in the network. Through a facility in the cloud, it is possible to access an excel file with all the materials shared, codes assigned and the hyperlink to get a pdf file of each material.

\section{What does the M@dNotes project propose?}

The project proposes a methodology for registering, sharing and preserving scientific production from the field of GP/FCM activity.

It is provided a system to share monographies, qualitative research reports, scientific reports, searches of materials, bibliographic references and resources or materials oriented to research, teaching or other purposes in health disciplines, ${ }^{12}$ emerging from Family and Community residency trainnig students, pregraduate students or general practitioners. All these documents and materials would stay where they are, in conferences settings, in universities repositories or on the networks. However, arranged or stored in that way they are not completely accessible or they cannot be found through the search engines. The Project provide a first step to do so. The objective is facilitate the knowledge exchange into the network. However, with the use of the world wide web all the contents are available everywhere. In the future to amplified the visibility wil be necesary to link the Project to open source or grey literature engines.

\section{Sharing and dissemination strategy}

The Project stimulate collaboration, team working and a way to share the knowledge through a web platform. In the case to share a references search on a particular topic we define a "non-systematic" method guided by centers of interest which allows registering the materials found. The design of the method does not allow getting systematic searches of scientific literature and it is not intended for systematic or exhaustive reviews. Nevertheless, it establishes a method to get, to list, to register, to share and to preserve searches of materials of diverse nature and on-line discussion by practicing healthcare providers.

Each search will be focused on the specific interest of each voluntary collaborator. The interest will be centered on a research question or particular curious interest. Many of the opinions, ideas or doubts that emerge to us are provoked by diverse stimuli that are not restricted to the scientific literature reading. It offers a strategy for sharing and preserving the searches made. It works as a reservoir of information, with free access and through a collaborative networking style in a volunteer non-profit platform. A tutorial to perform this method is available at: https://tinyurl.com/proyecto-NotasLocas

\section{Mad Notes step by step: share, disseminate, retrieve}

\section{How to share}

The platform allows sharing your scientific work and communicates your approach to knowledge your reflection or your questions with others. We have created a particular folder to fill up the tabs that each one wishes to share. Some of these tokens have been made and shared with generosity by experts on a particular topic, so they become excellent guides to bibliographic references and resources available in the global network. 
Then each one will follow its own interest and deepen these searches. After finishing your listing and if you wish, you can host it sending your draft to our e-mail address notaslocasmadnotes@gmail.com. Using a simple form we collect your data and you can upload your note to the cloud for dissemination. One time the document was uploaded we will add the codification (about the main topics of the work) and will validate the whole document with the collaborator in order to share and spread on the web blog and network resources. Recently we added a special space to upload and share monographic reports (non published medicine students and Family and Community training students reports).

\section{Editorial statement}

We have an editorial statement in order to guarantee the quality of the materials we publish and to ensure the consent of the authors. When we consider a scientific document non published for example a monographic report or conference report we apply the authors to atach the monographic tutors or scientific committee resolution about the acceptance of the work during the previous submission process to a scholar committee or to a conference.

After that, we ask the researcher to submit the paper on the drive through a web form and we ask the consent to publish and share on the web blog. For other reports or documents with not previous peer review we submit the application to revision for editorial board integrated for three volunteer members of the network. The documents shared by the platform are under a Creative Commons License CC BY-NC-ND. Licensees may copy, distribute, display and perform the work and make derivative works based on it only if they give the author or licensor the credits (attribution) in the manner specified by these. - Attribution + Noncommercial + NoDerivatives.

\section{Disemination strategy}

To facilitate dissemination was used a web blog as a communication interface. On the web blog is it possible to find documents following the tools provided: categories and tags. Categories are oriented to index on subjects for example "Primary Care" or "Commented articles" or "Monographies". Tags are associated to the codification tools; for example, QD42 Secondary prevention, in this case a Q Code. The whole project is indexed with Core Content Classification in GP/FCM (3CGP). This classification joins the International Classification of Primary Care (ICPC-2), used to identify clinical aspects and the Q-Codes, a proposal to identify contextual information about family physician profession.

Each note receives indexation with Q-Codes and or with ICPC 2. This effort will allow to retrieve the information in the network in a versatile mode adequate for the indexation of grey literature in GP/FM and Primary care. The full database is available in several languages in Excell file or in Web Ontology Language (OWL) format for semantic purposes. Refer to http://3cgp.docpatient.net/ for more information about the 3CGP project.

Descriptors of the $\mathrm{Q}$ Codes and ICPC are available in the following hyperlinks:

- Access to ICPC-2 Main Hierarchy (multilingual): https://hetop.eu/hetop/?la=en\&rr=CIP_C_ARBO

- Access to ICPC -2 Process Hierarchy (multilingual): https://hetop.eu/hetop/?la=en\&rr=CIP_C_ARBOPROC

- Access to $Q$ Codes Hierarchy (multilingual): https://www.hetop.eu/hetop/Q?la=en\&rr=CGP_CO_Q 
Table 1. Example of possible indexation tags.

\begin{tabular}{|ll|}
\hline Code & Name and Descriptor link \\
\hline \multirow{3}{*}{ Overscreening } \\
& ESP: http://www.hetop.eu/hetop/Q?la=es\&rr=CGP_QC_QD4\#la=es\&rr=CGP_QC_QD444\&tab=1\&q=Q \\
& EN: http://www.hetop.eu/hetop/Q?la=en\&rr=CGP_QC_QD4\#la=en\&rr=CGP_QC_QD444\&tab=1\&q=Q \\
& PT: http://www.hetop.eu/hetop/Q?la=en\&rr=CGP_QC_QD4\#la=pt\&rr=CGP_QC_QD444\&tab=1\&q=Q \\
& Malignant neoplasm prostate \\
& ES: https://www.hetop.eu/hetop/3CGP/es/?rr=CIP_D_Y77 \\
& EN: https://www.hetop.eu/hetop/3CGP\#rr=CIP_D_Y77\&q=Y77 \\
Y77 & PT: https://www.hetop.eu/hetop/3CGP/pt/?rr=CIP_D_Y77
\end{tabular}

Each entry allows to get a pdf file through a link with the document shared. On the front page of the document a metadata file is available with the name of the document, authors information, and indexation codes mentioned.

The following figure shows an example of metadata information.

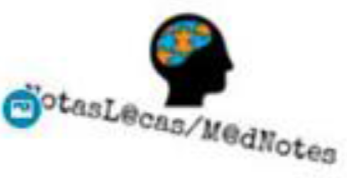

NOTASLECAS/MeDNOTES

Fichas de Notas y Referencias

/ Proyecto Colaborativo

Plataforma

QSaluDedenchufada /

Unplugged Healths Medicine.

https//tinyurlcom/Proyecto-

Notaslocas/Siquenos en

twitter eReciMadNotes

\section{Como ver todas ias}

fichas publicadas?

Comparte una NotaLeca

Indexación de las Notastecas / Códigos Q y CIAP 2
FICHA TÉCNICA DE LA NOTA / METADATOS:

EVIDENCIA SOBRE EL TRATAMIENTO DE LA

HIPERTENSIÓN ARTERIAL LEVE Y DE LA

HIPERURICEMIA EN ADULTOS.

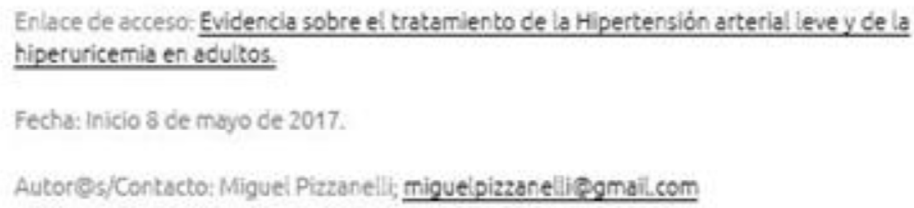

Enlace de acceso: Evidencia sobre el tratamiento de la Hipertensión arterial leve y de la hiperuricemia en adulcos.

Fecha: Inicio 8 de mayo de 2017.

Autores/Contacto: Miguei Pizzanelli; migueipizzanellipgmail.com

CODIFICACIÓN DE LA FICHA

\section{CÓDIGOS Q}

QD446: Sobretratamiento

Q51: Ambito de la Atención Primaria.

CODIFICACIÓN CIAP 2

K86: Hipertensión no complicada

K85: Gifras tensionales elevadas

A91: Resultado paraclinico anormal

\section{@) 00}

Figure 1. Metadata information available on the web blog. 
The first post in the web blog was publish on june 2017. Most of the entries are in Spanish, a few are in English and many others are multilingual. The authors are groups or individual contributors. Up to the moment 18 documents have being shared. There are Monographic reports, references sumaries, lists of materials and resourses, metanalisys reports and commented articles. On the following table is possible to see the topics covered.

Table 2. Some topics shared on NotasL@ cas

\begin{tabular}{|ll|}
\hline Type of communication & Subjects/Topics \\
\hline Monographic reports & Use of antiepilectics \\
& Breast cancer screening \\
Bibliographic references file & Overscreening \\
& HPV vaccine \\
& Colo rectal cancer screenind evidence \\
& Mammograms for breast cancer screening \\
Resources and material searches & Lipidic hypothesis \\
& Use of pharmacs and artistic expresions \\
& Deprescribing \\
Reports & ADHD \\
& Metaanalysis \\
& Scientific literature critical reading \\
\hline
\end{tabular}

\section{Retrieve}

It is possible to retrieve information or to perform a searh from the web blog tools using the indexation showed. Access of every document is possible and freely available.

\section{Availability}

- The project proposal and tutorial to share the notes are available here: https://tinyurl.com/proyecto-NotasLocas

- All notes are freely accessible in PDF: https://tinyurl.com/Fichas-Compartidas

- All notes are accessible on the network weblog: https://notaslocasmadnotes.wordpress.com/

\section{Coding the M@dNotes project itself}

M@dNotes itself as project supports the following Q-Codes:

- QT42/Online knowledge-sharing: Electronic Supplementary Materials [Publication Type]; Supporting content or information, such as animation, datasets, multimedia files, video, movies, audio files, text files, or software, which is submitted for publication in an online journal or an online edition of a journal. This information may be referenced in the text of the article with a link to the supplementary data provided. (MeSH). https://www.hetop.eu/hetop/Q?la=en\&rr=CGP_QC_QT42

- QT43/Digital Library: an online collection of digital objects, of assured quality, that is created or collected and managed according to internationally accepted principles for collection development 
and made accessible in a coherent and sustainable manner, supported by services necessary to allow users to retrieve and exploit the resources. (Scielo 2014) https://www.hetop.eu/hetop/Q?la=en\&rr=CGP_QC_QT43

- QT44/Social Media; Platforms that provide the ability and tools to create and publish information accessed via the INTERNET. Generally, these platforms have three characteristics with content user generated, a high degree of interaction between creator and viewer, and easily integrated with other sites. (MeSH) https://www.hetop.eu/hetop/Q?la=en\&rr=CGP_QC_QT44

\section{Final note: mision and conflict of interest}

Mad Notes is a volunteer and non-profit international, industry- independent initiative.

Mad Notes offers to collaborate in an independent worldwide non-profit network. We promote solidarity, voluntary networking and a space of critical thinking and collective creation for open-minded general practitioners and primary care workers. The project is being supported for some passionate colleagues. This article is also an invitation for volunteers willing to contribute to the dissemination of quality information.

\section{References}

1. Eysenbach G. Medicine 2.0: Social Networking, Collaboration, Participation, Apomediation, and Openness. J Med Internet Res. 2008;10(3):e22.

2. Eysenbach G, Diepgen TL. Towards quality management of medical information on the internet: evaluation, labelling, and filtering of information. BMJ. 1998;317(7171):1496-500. https://doi.org/10.1136/bmj.317.7171.1496

3. Biblioteca Universitaria. Biblioguías: Recursos de información en Economía, Empresa y Turismo: Literatura gris [Internet]. [cited 2017 Oct 2]. Available from: http://biblioguias.ulpgc.es/c.php?g=594832\&p=4342143

4. Schöpfel J, Farace D. Grey Literature. In: Bates M, Maack M, eds. Encyclopedia of Library and Information Sciences. 3rd ed [Internet]. Boca Raton: CRC Press; 2010 [cited 2017 Oct 7]. p. 2029-39.

5. Grey Literature and Policy Development [Internet]. [cited 2017 Oct 7]. Available from: http://www.greynet.org/greyforumseries/ policydevelopment.html

6. Jamoulle M, Resnick M, Ittoo A, Vander Stichele R, Cardillo E, Grosjean J, et al. Indexing grey multilingual literature in General Practice in the era of Semantic Web. 2017 [cited 2017 Oct 7]; Available from: http://orbi.ulg.ac.be/handle/2268/210490

7. Mejia CR, Valladares-Garrido MJ, Miñan-Tapia A, Serrano FT, Tobler-Gómez LE, Pereda-Castro W, et al. Use, knowledge, and perception of the scientific contribution of Sci-Hub in medical students: Study in six countries in Latin America. PLoS One. 2017;12(10):e0185673.

8. Gotzsche PG. Deadly Medicines and Organised Crime: How Big Pharma Has Corrupted Healthcare. Abingdom: Radcliffe Publishing; 2013.

9. Moynihan R. Who pays for the pizza? Redefining the relationships between doctors and drug companies. 2: Disentanglement. BMJ [Internet]. 2003 May 31 [cited 2017 Oct 7];326(7400):1193-6. Available from: https://www.ncbi.nlm.nih.gov/pmc/articles/PMC1126054/

10. Bernstein J, La Valle R, Piñero A., y cofirmantes. La salud como resistencia: un manifiesto por la prevención cuaternaria. nogracias.eu. 2016. http://www.nogracias.eu/2016/12/26/la-salud-como-resistencia-un-manifiesto-por-la-prevencion-cuaternaria/

11. Pizzanelli M, Almenas M, Quirós R, Pineda C, Cordero E, Taureaux N, et al. Prevenção Quaternária: Ética Médica, Avaliação e Eficiência nos Sistemas de Saúde. Rev Bras Med Fam Comunidade [Internet]. 2016 Oct 29 [cited 2016 Nov 16];11(0):75-85. Available form: https:// www.rbmfc.org.br/rbmfc/article/view/1388

12.Pizzanelli M. ¿Qué es NotasL@cas?/What M@dNotes is? [Internet]. 2017 [cited 2017 Oct 2]. Available from: https://notaslocasmadnotes.wordpress.com/2017/06/27/primera-entrada-del-blog/ 